DOI: https://doi.org/10.24127/ajpm.v10i2.3663

\title{
DESCRIPTION OF THE DIFFICULTY OF STUDENTS' MATHEMATICS PROBLEM SOLVING ASSESSED FROM ADVERSITY QUOTIENT (AQ)
}

\author{
Amiratih Siti Aisyah ${ }^{1 *}$, Riyadi $^{2}$, and Sri Subanti ${ }^{3}$ \\ ${ }^{1 *, 2,3}$ Department of Mathematics, Universitas Sebelas Maret, Indonesia \\ * Jl.Ir Sutami 36A Kentingan Jebres, Surakarta, 57126, Indonesia. \\ E-mail: $\quad$ amiratih.asa@gmail.com $^{\left.{ }^{*}\right)}$ \\ riyadifkipuns@gmail.com ${ }^{2)}$ \\ sri_subanti@yahoo.co.id ${ }^{3)}$
}

Received 04 April 2021; Received in revised form 14 June 2021; Accepted 29 June 2021

\begin{abstract}
This study aims to determine the difficulty of solving mathematic problems among students AQ climbers, AQ campers, and AQ quitters. This type of research was qualitative research with a descriptive approach. The subject of this study is the 3rd grade of XI MIPA Batik High School 2 Surakarta in the academic year 2020/2021 which constitutes 6 students. The subject taking was done by giving an adversity quotient questionnaire. From the results of filling out the questionnaire, the subjects were categorized based on their AQ. Furthermore, given a mathematic problem-solving test. After seeing the test results, three subjects representing AQ climbers, AQ campers, and AQ quitters were selected purposively for further interviews. The results showed: 1) The climbers subject experienced two difficulties in solving mathematic problems, namely difficulties in understanding problems and difficulties in implementing plans. 2) The subject of the campers has three difficulties in solving mathematic problems, namely difficulties in understanding problems, difficulties in implementing plans, and difficulties in reviewing. 3) The quitters subject experiences four difficulties in solving mathematic problems, namely difficulties in understanding problems, difficulties in planning, difficulties in implementing plans and difficulties in reviewing, and difficulties in revisiting.
\end{abstract}

Keywords: Adversity quotient; description; difficulty; problem solving.

\begin{abstract}
Abstrak
Penelitian ini bertujuan untuk mengetahui kesulitan pemecahan masalah matematika siswa AQ climbers, $A Q$ campers dan $A Q$ quitters. Jenis penelitian ini adalah penelitian kualitatif dengan pendekatan deskriptif. Subjek pada penelitian ini adalah siswa kelas XI MIPA 3 SMA Batik 2 Surakarta tahun ajaran 2020/2021 yang berjumlah 6 siswa. Pengambilan subjek dilakukan dengan memberikan angket adversity quotient. Dari hasil pengisian angket dilakukan pengkategorian subjek berdasarkan AQ yang dimilikinya. Selanjutnya diberikan tes pemecahan masalah matematika. Setelah melihat hasil tes, dipilih secara purposif tiga subjek yang mewakili siswa AQ climbers, AQ campers, dan AQ quitters untuk diwawancarai lebih lanjut. Hasil penelitian menunjukkan: 1) Subjek climbers mengalami dua kesulitan dalam mengerjakan soal pemecahan masalah matematika yaitu kesulitan dalam memahami masalah dan kesulitan dalam melaksanakan rencana. 2) Subjek campers mengalami tiga kesulitan dalam mengerjakan soal pemecahan masalah matematika yaitu kesulitan dalam memahami masalah, kesulitan dalam melaksanakan rencana, dan kesulitan dalam meninjau kembali. 3) Subjek quitters mengalami empat kesulitan dalam mengerjakan soal pemecahan masalah matematika yaitu kesulitan dalam memahami masalah, kesulitan dalam menyusun rencana, kesulitan dalam melaksanakan rencana dan kesulitandalam meninjau kembali.
\end{abstract}

Kata kunci: Adversity quotient, deskripsi, kesulitan, pemecahan masalah

This is an open access article under the Creative Commons Attribution 4.0 International License 
DOI: https://doi.org/10.24127/ajpm.v10i2.3663

\section{INTRODUCTION}

According to Khasanah \& Sutama (2015), the difficulties experienced by students will allow errors to occur when solving questions. This confirms that adversity was the cause of errors. The difficulty was a condition that shows the characteristics of obstacles in activities to achieve goals (Anisah \& Sri Lastuti, 2019), so a better effort was needed to overcome it.

Errors were deviations from what was true or deviations from what has been previously established (Dewi, S.I.K and K, 2014). Amelia (2016) and Jana (2018) suggested that there were several types of errors that students make in solving math problems.

Problem-solving ability was a very important skill (Akbar et al., 2017; Mawaddah \& Anisah, 2015) and become the main focus for students to have and develop through learning mathematics in schools. The main goal of learning mathematics was to solve math problems (Christidamayani, 2020). Based on the results of the program for international student assessment (PISA) assessment, around $71 \%$ of students didn't reach the minimum level of competency in mathematics, which means that many Indonesian students have difficulty in dealing with situations that require problem-solving skills.

The problem-solving process is a complex process that requires flexible and dynamic thinking. Students can use various strategies in finding the right solution to the problem faced (Nur \& Palobo, 2018). It is in line with Purwaningsih and Ardani (2020) who state that problem-solving ability is a fundamental skill in learning mathematics, so problem-solving skills should be taught to the students at the beginning so that the expected results can be achieved properly. The indicators of solving mathematical problems according to Polya in Ifanali, (2014) and Yarmayani, (2016), are understanding the problem, planning the solution, solving the problem based on plan, and checking the final solution.

This study focuses on describing students' difficulties in solving math problems in terms of the adversity quotient (AQ). Stoltz (2000) believes that a person's achievement can be determined by the level of Adversity Quotient (AQ) one has. The higher a person's Adversity Quotient (AQ), the better the achievement he/she has.

Adversity Quotient (AQ) was a person's resilience in facing the difficulties he was experiencing (Aryono, 2017; Merianah, 2019). The adversity quotient was a person's persistence when facing obstacles to success (Suryaningrum, 2020). Each person's adversity quotient (AQ) was different. The levels of adversity quotient (AQ) were grouped into 3 categories, namely (Abdiyani et al., 2019; Yanti \& Syazali, 2016): climbers, campers, and quitters. Climbers were a group of people who always try to face obstacles to reach the peak of success, or it can be called a high Adversity quotient (AQ). (E. Y. S. S. Dewi, Mayangsari, \& Fauzia, 2017; Saidah \& Lailatuzzahro, Al-Akhda, 2014). Campers were a group of people who have business in facing obstacles but were easily satisfied with what they have achieved so they do not reach the peak of success, or it can be called moderate Adversity Quotient (AQ). (Hardianto \& Sucihayati, 2019; Maini \& Izzati, 2019; Putra et al., 2016). Meanwhile, quitters were a group of people who easily give up in the face of obstacles, or what can be called low Adversity Quotient (AQ) (Apriliani et 
al., 2018; Purwanti, 2019). According to Stoltz, people with the climbers' type tend to choose to continue to struggle and do not give up easily in facing various kinds of problems, so that the results obtained were better than people with the type of campers and quitters (Septianingtyas \& Jusra, 2020). People with the campers type tend to be easily satisfied with what has been achieved so that the results obtained were not optimal. Meanwhile, people with the quitters' type tend not to be passionate about solving a problem and even give up before making an effort, so the results obtained were also unpredictable (Kartikaningtyas, Kusmayadi, \& Riyadi, 2018; Rany, 2015). It is in line with Hidayat (2018) who states that quitters students' give up easily because of the difficulties in the problem-solving process they face.

Several researchers have conducted research related to mathematical problem solving and adversity quotient. Lisa Dwi Afri (2018) states that the adversity quotient has a positive relationship and a significant influence on students' mathematical problemsolving abilities, so it can be said that the higher the adversity quotient, the higher the students' mathematical problem-solving abilities.

The presentation of several types of research and problems that have been presented relates to the difficulties in solving mathematical problems and the adversity quotient of students in solving mathematical problems. Thus, this research leads to novelty and originality about difficulties in solving mathematical problems which are reviewed from the adversity quotient of students. Based on the description, this study aims to describe the difficulties of students in solving mathematical problems in terms of Adversity Quotient (AQ).

\section{METHOD}

This type of research was qualitative research with a descriptive approach. The subjects in this study were six students of class XI SMA Batik 2 Surakarta. The selection of subjects was based on data obtained from the Adversity quotient (AQ) questionnaire and problem-solving tests. In this research, the problem-solving indicators can be seen in Table 1 .

Table 1. Mathematical problem-solving indicator

\begin{tabular}{|c|c|c|}
\hline No & Indicator & Criteria \\
\hline 1 & $\begin{array}{l}\text { Understand } \\
\text { the problem }\end{array}$ & $\begin{array}{l}\text { Students were said to understand problems when students were able to } \\
\text { determine the information that was known and asked about the questions } \\
\text { and students were able to identify information from the questions given. }\end{array}$ \\
\hline 2 & $\begin{array}{l}\text { Plan a } \\
\text { solution }\end{array}$ & $\begin{array}{l}\text { Students were said to plan the solution when students were able to make } \\
\text { mathematical models on story problems and students were able to plan } \\
\text { appropriate completion strategies for solving problems. }\end{array}$ \\
\hline 3 & $\begin{array}{l}\text { Resolve } \\
\text { problems } \\
\text { according to } \\
\text { plan }\end{array}$ & $\begin{array}{l}\text { Students were said to solve problems according to plan when students } \\
\text { were able to operate the steps for completion and students were able to } \\
\text { operate the calculation correctly. }\end{array}$ \\
\hline 4 & $\begin{array}{l}\text { Check back } \\
\text { the results of } \\
\text { the } \\
\text { completion }\end{array}$ & $\begin{array}{l}\text { Students were said to re-examine the results of their solutions when } \\
\text { students were able to determine the final answer of solving the } \\
\text { questions, students were able to make conclusions from solving the } \\
\text { questions and students check the results of their solutions again. }\end{array}$ \\
\hline
\end{tabular}


Based on the scoring category of the adversity quotient (AQ) questionnaire according to Stoltz (2000), students who had scores between 135 and 200 were included in the climbers' category. Students who have a score between 60 and 134 were included in the campers' category. And students with scores between 0 and 59 fall into the quitters' category. Furthermore, based on the test results, 1 student was selected purposively from each category. The details of each selected subject were presented in Table 2 .

Table 2. Retrieval of research subjects

\begin{tabular}{ccc}
\hline $\begin{array}{c}\text { Student } \\
\text { Code }\end{array}$ & $\begin{array}{c}\text { Questionnaire } \\
\text { Score }\end{array}$ & $\begin{array}{c}\text { Category } \\
\text { AQ }\end{array}$ \\
\hline S-01 & 144 & Climbers \\
S-02 & 111 & Campers \\
S-03 & 57 & Quitters \\
\hline
\end{tabular}

Data collection techniques in this study include questionnaires, tests, and interviews. The research instruments used included the Adversity Quotient (AQ) questionnaire, mathematic problem-solving tests, and interview guides. All research instruments have been validated by experts. In this study, the validity of the data can be checked through a method triangulation. Method triangulation was used to compare the test and interview methods of several students using different methods. Data analysis techniques in this study used the Miles and Huberman Model (Budiyono, 2019: 161), namely data reduction, data presentation, and conclusion/ verification.

\section{RESULTS AND DISCUSSION}

\section{Difficulty Description S-01 and S-02 (Climbers)}

The student's mathematical problem-solving result with AQ climbers can be seen in Figure 1 and 2 .

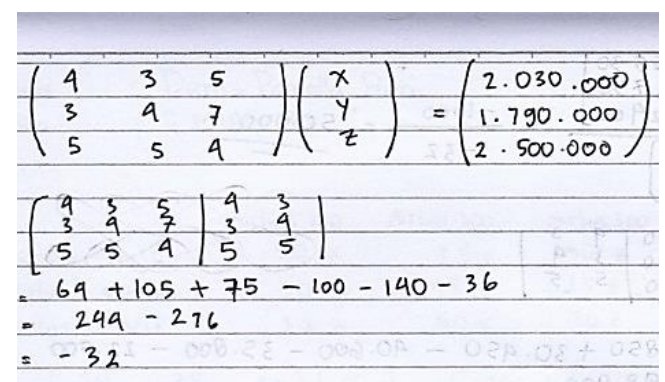

Figure 1. Results of the mathematic problem-solving test $\mathrm{S}-01$

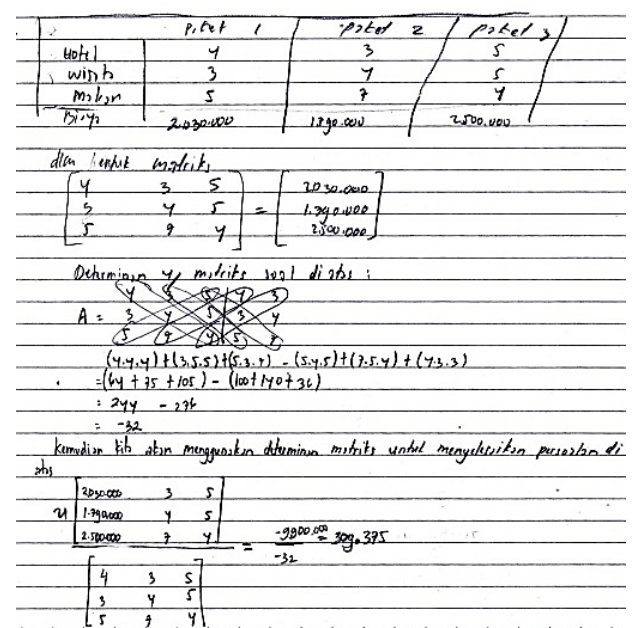

Figure 2. Results of the mathematic problem-solving test $\mathrm{S}-02$

Based on the tests and interviews that have been done, it appears that the climbers' subjects had less difficulty in solving the problem than the campers' and quitters' subjects. The climbers' subjects experienced two difficulties in understanding the problem and difficulties in implementing the plan.

First, namely the difficulty in understanding the problem, S-01 and S02 were able to identify information from the questions given. However, S01 and S-02 still had difficulty understanding the questions. S-01 and S-02 did not write down what was known and asked about the questions. S-01 and S-02 did not write down a mathematical model but instead wrote a solution directly. 
DOI: https://doi.org/10.24127/ajpm.v10i2.3663

The second was the difficulty in implementing the plan, S-01 and S-02 were able to operate the settlement steps. S-01 and S-02 were still experiencing difficulties in operating the count. S-01 and S-02 experienced obstacles in calculating the determinant of the order $3 \times 3$ matrix, causing an error in determining the final answer to solving the problem.

\section{Difficulty Description S-03 and S-04 (Campers)}

The student's mathematical problem-solving result with AQ campers S-03 and S-04 can be seen in Figure 3 and Figure 4.

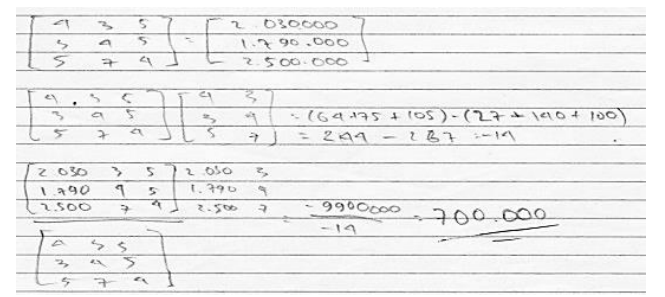

Figure 3. Results of the S-03 mathematic problem-solving test

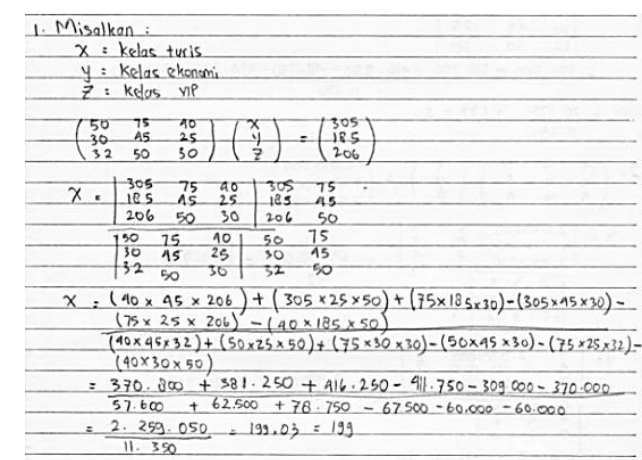

Figure 4. Results of the S-04 mathematic problem-solving test

Based on the tests and interviews, the campers' subjects had less trouble than the quitters' subjects. The campers' subjects got three difficulties in working on problem-solving problems, namely difficulties in understanding problems, difficulties in implementing plans, and difficulties in reviewing.
First, the difficulty in understanding the problem, S-03 and S04 were able to identify information from the questions given. However, S03 still has difficulty understanding what was known from the questions. S03 and S-04 don't write down what was known and asked about the questions. S-03 does not write a mathematical model but instead writes a solution strategy directly.

Second, namely the difficulty in implementing the plan, S-03 and S-04 were able to operate the settlement steps. They were still experiencing difficulties in operating the count. They experienced obstacles in calculating the determinant of the order $3 \times 3$ matrix, causing an error in determining the final answer to solving the problem.

And third, namely the difficulty in reviewing it, S-03 and S-04 experienced obstacles in determining the final answer to the problem solving because of errors in operating the calculation on the determinant of the matrix. They don't make conclusions from the story problems given. They also don't doublecheck of the solution was true or false.

\section{Description of Difficulty S-05 and S- 06 (Quitters)}

The student's mathematical problem solving result with AQ quitters S-05 and S-06 can be seen in Figure 5 and Figure 6.

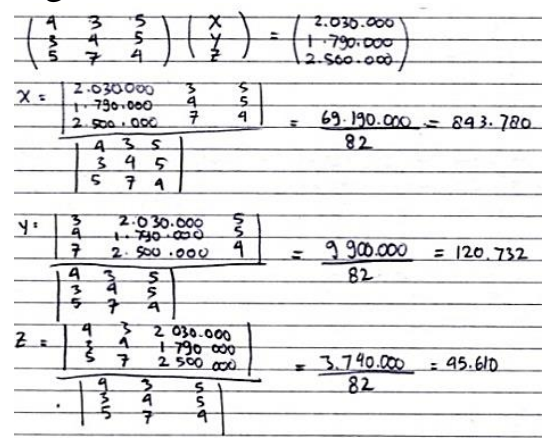

Figure 5. Results of the S-05 mathematic problem-solving test 
DOI: https://doi.org/10.24127/ajpm.v10i2.3663

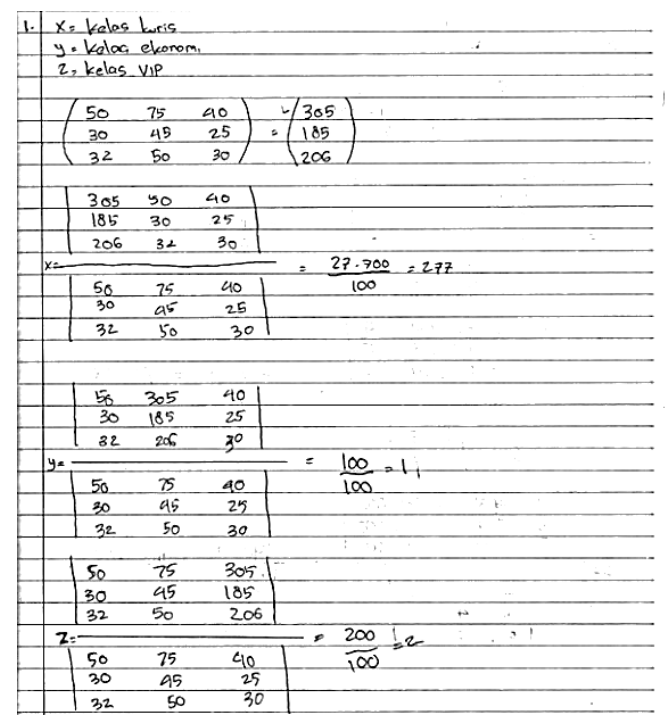

Figure 6. Results of the S-06 mathematic problem-solving test

Based on the tests and interviews that have been done, it appears that the subject quitters had the most trouble solving problems. The quitters subject experienced four difficulties in solving problem-solving problems, namely difficulties in understanding problems, difficulties in planning, difficulties in implementing plans, and difficulties in reviewing.

First, the difficulty in understanding the problem, S-05 and S-06 were unable to identify information from the questions given. S-05 still has difficulty understanding what was known and asked from the questions. S05 and S-06 didn't write down what was known and asked about the questions.

Second, the difficulty in planning, S-05, and S-06 experienced obstacles in making mathematical models on the given story problems. S-05 and S-06 don't write a mathematical model but directly writes the steps for solving it. S-05 and S-06 were still experiencing obstacles in planning the appropriate completion strategy in solving problems. S-05 and S-06 were still experiencing obstacles in determining the concept that corresponds to the problem, namely the concept of matrix determinants. S-05 and S-06 still don't understand the concept of how to spell the determinant of the order $3 \times 3$ matrix.

The third was the difficulty in implementing the plan, S-05 and S-06 don't know how to operate the $3 \times 3$ determinant. S-05 and S-06 were still experiencing difficulties in operating the count. And fourth, namely the difficulty in reviewing it, S-05 and S-06 were able to determine the final answer to solving the problem. S-05 and S-06 have not written any conclusions about this solution. S-05 and S-06 have not checked again whether the solution was correct or not.

The types of difficulties experienced by S-01, S-02, S-03, S-04, $\mathrm{S}-05$, and S-06 were presented in Table 3.

Table 3. Types of subject difficulties

\begin{tabular}{lccc}
\hline \multicolumn{1}{c}{ Types of Subject } & S-01 \& & S-03 \& & S-05 \& \\
Difficulties & S-02 & S-04 & S-06 \\
\hline $\begin{array}{l}\text { Difficulty } \\
\text { understanding the }\end{array}$ & $\checkmark$ & $\checkmark$ & $\checkmark$ \\
problem & & & \\
$\begin{array}{l}\text { Difficulty planning } \\
\text { Difficulty }\end{array}$ & & & $\checkmark$ \\
$\begin{array}{l}\text { executing plans } \\
\text { Difficulty in } \\
\text { reviewing }\end{array}$ & $\checkmark$ & $\checkmark$ & $\checkmark$ \\
\hline
\end{tabular}

\section{Subject Type of Difficulty}

From Table 3, the climbers subject tended to have less difficulty in solving mathematic problems than the campers and quitters subjects. Meanwhile, campers subjects tended to have less difficulty solving math problems than quitters subjects. This was following the theory of Stoltz (Ellasari and Wibowo, 2019; Fitri Alyani, 2020; Khumairoh, Amin, \& Wijayanti, 2020) who said that people with the climbers' type tend to choose to continue to struggle and do not give up easily in facing various kinds of problems so that the results 
obtained were better than people with the type of campers and quitters. People with the campers type tend to be easily satisfied with what has been achieved so that the results obtained were not optimal (Septianingtyas \& Jusra, 2020). Meanwhile, quitters tend to be discouraged (Hanum, 2018; Mafulah \& Amin, 2020; Sunandi \& Supratman, 2019) in solving a problem even giving up before making an effort, so that the results obtained cannot be expected.

Mathematical problem solving is one of the abilities that every student must have. However, in reality, students' mathematical problem-solving is still relatively low. This can be seen from the result of the analysis of this study which concluded that students who have the adversity quotient in the categories of climbers, campers, and quitters still have difficulty in solving mathematic problems.

The results of this study are a note for teachers that adversity quotient is one of the students' abilities in dealing with difficulties in mathematical problem-solving. By knowing the difficulties of students in mathematic problem solving on matrix material, teachers can find out what things must be prepared in preparing students based on the adversity quotient to solve mathematics problems.

The result of this study also supported the research done by Meiranah (2019), which claims that the adversity quotient is a direct influence on mathematical problem-solving. The higher the fighting power (adversity quotient) possessed by a student, the higher the mathematical problemsolving ability contained in the student. It is in line with Amirullah, Mulbar, \& Djam'an, (2019) who state that climbers students tend to have less difficulties than campers and quitters students.

\section{CONCLUSION AND SUGGESTION}

The climbers' students tended to experience less difficulty in solving problems compared to the campers' and quitters' students. The climbers' students experienced two difficulties in solving mathematic problems, namely difficulties in understanding the problem and difficulty in implementing the plan.

Campers' students tend to have less trouble solving problems than quitters students. Campers' students experience three difficulties in solving mathematic problems, namely difficulties in understanding problems, difficulties in implementing plans, and difficulties in reviewing.

Quitters' students tend to have the most difficulty solving problems. Quitters' students experience four difficulties in solving mathematic problems, namely difficulties in understanding problems, difficulties in planning, difficulties in implementing plans, and difficulties in reviewing.

The results of this study indicate the types of difficulties experienced by students climbers, campers, and quitters, in solving mathematic problems, especially on matrix material. The suggestion for further research is to be able to do another study that illustrates the difficulties experienced by climbers, campers, and quitters students on different materials.

\section{REFERENCES}

Abdiyani, S. S., Khabibah, S., \& Rahmawati, N. D. (2019). Profile of Mathematical Problem Solving Ability of Students of SMP Negeri 1 Jogoroto Based on Polya's Steps in terms of Adversity Quotient. AlKhwarizmi: Journal of Mathematics and Natural Sciences Education, 7(2), 123-134. https://doi.org/10.24256/jpmipa.v7i 
DOI: https://doi.org/10.24127/ajpm.v10i2.3663

\subsection{4}

Afri, L. D. (2018). The Relationship Between Adversity Quotient and The Problem Solving Ability of Junior High School Students in Learning Mathematics. AXIOM: Journal of Education and Mathematics, 7(2), 47-53.

Akbar, P., Hamid, A., Bernard, M., \& Sugandi, A. I. (2017). Analysis of Problem Solving Ability and Mathematical Disposition of Class XI SMA Putra Juang Students in Opportunity Material. Journal Cendekia : Journal of Mathematics Education, 2(1), 144-153. https://doi.org/10.31004/cendekia.v $2 \mathrm{i} 1.62$

Amelia, W. (2016). Characteristics and Types of Learning Difficulties in Slow Learner Children. Aisyah's Journal : Journal of Health Sciences, 1(2), 53-58. https://doi.org/10.30604/jika.v1i2.2 1

Amirullah, Mulbar, U., \& Djam'an, N. (2019). Description of Students' Mathematics Problem Solving Difficulties in terms of Adversity Quotient. Issues in Mathematics Education, 3(1), 22-29. http://www.ojs.unm.ac.id/imed

Anisah, \& Sri Lastuti. (2019). Identification of Mathematical Problem Solving Abilities for Prospective Elementary School Teachers at STKIP Taman Siswa Bima and How to Develop them. MIPA EDUCATION JOURNAL, 9(2), $\quad$ 101-111. https://doi.org/10.37630/jpm.v9i2. 217

Apriliani, U., Wasidi, W., \& Sholihah, A. (2018). The Relationship Between Adversity Quotient (AQ) and Academic Procrastination of Class X Students of SMA Negeri 5
Bengkulu City. Consilia : Scientific Journal of Guidance and Counseling, 1(3), 12-23. https://doi.org/10.33369/consilia.1. 3.12-23

Aryono, S. Y., Machmuroch, \& Karyanta, N. A. (2017). Relationship between Adversity Quotient and Emotional Maturity with Tolerance to Stress in Nature Lovers of Sebelas Maret University. Discourse Journal, 9(18), 12-27. http://jurnalwacana.psikologi.fk.un s.ac.id/index.php/wacana/article/vi ew/108

Christidamayani, A. P., \& Kristanto, Y.D. (2020). The Effects of Problem Posing Learning Model on Students' Learning Achievement and Motivation. ArXiv, 2008, 100-108.

Dewi, E. Y. S. S., Mayangsari, M. D., \& Fauzia, R. (2017). Relationship between Adversity Quotient and Resilience in Advanced-Stage Cancer Patients. Ecopsy Journal, 3(3), 133-139. https://doi.org/10.20527/ecopsy.v3i 3.2664

Dewi, S. I. K. and K. (2014). Analysis of the Errors of Class VIII Students in Solving Problems on the Matter of Factorization of Algebraic Forms of State Junior High School 1 Kamal Odd Semester Academic Year 2013/2014. MATHEdunesa Scientific Journal of Mathematics Education, 3(2), 195-202.

Ellasari, M. \& Wibowo, T. (2019). Climbers Students' Mathematical Reasoning Level in Solving Pisa Problems. PROCEEDINGS

Fitri Alyani, R. Z. (2020). Application of The Rasch Model: Analysis of the Adversity Quotient of Students in Mathematics. Math Didactic: 
DOI: https://doi.org/10.24127/ajpm.v10i2.3663

Journal of Mathematics Education, 6(2), 226-234.

Hanum, L. (2018). Differences in Student Adversity Intelligence by Gender. HONAI: International Journal for Educational, Social, Political \& Cultural Studies 1(2), 115-128.

Hardianto, Y., \& Sucihayati, R. B. (2019). The Relationship between Adversity Quotient and Career Adaptability in the 2015 KOAS FKG $X$ at RSGM. Psibernetika. https://doi.org/10.30813/psiberneti ka.v11i2.1433

Hidayat, W., Wahyudin, Prabawanto, S. (2018). The Mathematical Argumentation Ability and Adversity Quotient (AQ) of PreService Mathematics Teacher. Journal on Mathematics Education, 9(2), 239-248.

Ifanali. (2014). Application of Polya's Steps to Improve Problem Solving Ability of Story Solving Questions in Grade VII Students of SMP Negeri 13 Palu. Jurnal Elektronik Pendidikan Matematika Tadulako, 1(3), 147-158. http://jurnal.untad.ac.id/jurnal/inde x.php/JEPMT/article/view/3217

Jana, P. (2018). Analysis of Student Errors in Solving Mathematical Problems on Vector Subjects. Mercumatika Journal: Mathematics Research Journal and Mathematics Education, 2(2), 8. https://doi.org/10.26486/jm.v2i2.3 98

Kartikaningtyas, V., Kusmayadi, T. A., \& Riyadi, R. (2018). The Effect of Brain-Based Learning with Contextual Approach Viewed from Adversity Quotient. Journal of Physics: Conference Series, 1022(1).

https://doi.org/10.1088/1742-

\section{6/1022/1/012014}

Khasanah, U., \& Sutama. (2015). Difficulty Completing Mathematics Story Questions in Junior High School Students. Proceeding of the 2015 UMS National Mathematics Education Seminar.

Khumairoh, B., Amin, S. M., \& Wijayanti, P. (2020). Middle-Grade Student Proportional Reasoning in Solving Mathematical Problems in terms of Adversity Quotient. Pedagogia: Journal of Education. https://doi.org/10.21070/pedagogia .v9i1.259

Mafulah, J., \& Amin, S. M. (2020). Students' Mathematical Connection Ability in Solving Mathematical Problems in terms of Adversity Quotient. MATHEdunesa, 9(1), 241-250.

https://doi.org/10.26740/mathedun esa.v9n2.p241-250

Maini, N., \& Izzati, N. (2019). Analysis of Students' Mathematical Problem Solving Ability Based on Bransford \& Stein's Steps in terms of Adversity Quotient. Jurnal Kiprah, 7(1), 32-40. https://doi.org/10.31629/kiprah.v7i 1.1175

Mawaddah, S., \& Anisah, H. (2015). Students' Mathematical Problem Solving Ability in Mathematics Learning by Using in SMPN Generative Learning Model in Junior High School. EDU-MAT: Journal of Mathematics Education, 3(2), 166-175. https://doi.org/10.20527/edumat.v3 i2.644

Merianah, M. (2019). The Influence of Emotional Intelligence and Adversity Quotient on The Mathematical Problem Solving Ability of SDIT IQRA'1 Students 
DOI: https://doi.org/10.24127/ajpm.v10i2.3663

in Bengkulu City. Raflesia Mathematics Education Journal, 4(1), 29-35. https://doi.org/10.33449/jpmr.v4i1. 7526

Nur, A. S. \& Palobo, M. (2018). Profile of Mathematics Problem Solving Ability Study in Terms of Difficult in Cognitive Style and Gender. Creative-Innovative Mathematics Journal, 9(2), 139-148.

Purwaningsih, D \& Ardani, A. (2020). Mathematic Problem Solving Ability Material Exponent and Logaritma Viewed from Learning Styles and Gender Difference. AKSIOMA: Journal of Mathematics Education Study Program, 9(1), 118-125.

Purwanti, P. (2019). Analysis of the Level of Adversity Quotient (AQ) of High School Students in Mathematics Learning through Problem Based Learning ( PBL ). Proceedings of the 2019 National Seminar on Mathematics and Mathematics Education for Sesiomadika.

Putra, M. R. G., Hidayati, N. O., \& Nurhidayah, I. (2016). The Relationship between Achievement Motivation and Adversity Quotient for Youth Assisted Citizens in LPKA Class II Sukamiskin Bandung. Indonesian Journal of Nursing Education, 2(1), 52-61. https://doi.org/10.17509/jpki.v2i1. 2853

Rany, W. (2015). Thinking Process of Students in Solving Mathematical Problems based on the Theory of Polya in terms of the Climbers Type Adversity Quotient. AlJabar: Journal of Mathematics Education, 6(2), 183-193.

Saidah, S., \& Lailatuzzahro, Al-Akhda, A. (2014). The Relationship between Self-Efficacy and Adversity Quotient (AQ). Journal of Psychology, 2(2), 54-61.

Septianingtyas, N., \& Jusra, H. (2020). Students' Mathematical Problem Solving Ability Based on Adversity Quotient. Journal Cendekia: Journal of Mathematics Education, 4(2), 657-672. https://doi.org/10.31004/cendekia.v $4 \mathrm{i} 2.263$

Stoltz, P. G. (2000). Adversity Quotient: Turn Obstacles into Opportunities. Jakarta: Grasindo.

Sunandi, \& Supratman. (2019).Students' Creative Thinking Process in Mathematical Problem Solving in terms of Adversity Quotient Based on Wallas' Model. National Seminar Proceeding \& Call For Papers, 552-561.

Suryaningrum, C. W., Purwanto, Subanji. (2020). Semiotic Reasoning Emerges in Constructing Properties of a Rectangle A Study of Adversity Quotient. Journal on Mathematics Education, 11(1), 95-110.

Yanti, A. P., \& Syazali, M. (2016). Analysis of Students' Thinking Process in Solving Mathematical Problems based on Bransford and Stein's Steps in terms of Adversity Quotient. Al-Jabar: Journal of Mathematics Education, 7(1), 6374.

https://doi.org/10.24042/ajpm.v7i1. 132

Yarmayani, A. (2016). Analysis of The Mathematical Problem Solving Ability of Students of Class XI MIPA Senior High School 1 Jambi City. Dikdaya Scientific Journal, 12-19. 